\title{
Hungarian Education Reforms and Challenges after the Global Financial Crisis
}

\author{
Qing-Nian Wang \\ International Office, \\ South China University of Technology, \\ Guangzhou, China \\ E-mail: adqnwang@sina.com
}

\author{
Yu-Jie Qin \\ School of Environment and Energy, \\ South China University of Technology, \\ Guangzhou, China \\ E-mail: qinyujie@scut.edu.cn
}

\begin{abstract}
Hungary in a certain historical period, its higher education on the implementation of strategic planning, strategic measures, the uniqueness of its higher education, the modern and the modern economy, and the development of the society has extremely far-reaching influence. In many Nobel Prize laureates, there are 13 of them who were born or grew up in Hungary. This paper focuses on Hungarian higher education thought, education system, the main task of higher education and its planning, higher education laws and regulations, personnel training, higher education reform and the situation of the policy support. Especially after the Global Financial Crisis, personnel training and education power policy, worth thinking about. Knowledge and understanding of Hungary in the past, the present situation and future development trend of higher education, the research of the current education development strategy planning, strategic measures and achievements, to promote the education strategy, have certain reference significance.
\end{abstract}

Keywords-Hungarian education; reform; challenge; global financial crisis

\section{INTRODUCTION}

Hungary is a landlocked country in central Europe, covers an area of 9.30 square kilometers, population 10.04 million, Hungarians' accounts for about 98\%. The current name for the Republic of Hungary was changed in 1989. There are about 249000 full-time undergraduate students, and the foreign students accounted for about 5\%; while there are about 994000 Middle school students and its studentfaculty ratios is 1:10. The 6-year elementary student reaches 428000 , and its student-faculty ratios for 1:10.4. There are 378000 preschool children, its student-faculty ratios for $1: 10.6$.

Hungary is the one who joined the Bologna process early in Central and Eastern Europe. According to the requirements of the Bologna process, Hungary in the several years should be complete transformation in the field of education. At present, the Hungarian basic education is in a transition stage for a long time. About $70 \%$ of the students choose directly to attend college after high school, $30 \%$ students choose to work a few years to go to college. In Hungary, basically every basic can college students. Especially the after school reading of vocational school students, if applied, can go to college. Hungary for twelve years of compulsory education (eight years of primary education and four-year high school education).The first school was founded in 998, is located in Western Hungary (Pannonhalmi ) class was open, which the Pope purposed to build for Hungary's founding ceremony of the church pastor. The Hungarian parliament as early as 1868 years have passed the national compulsory education basic law, than was famous for its national compulsory education which was the first in the world, two years earlier than UK $[1,2,3,4,5,6,7]$.

Hungary's current education system contains from preschool education, the school system and teaching institutions outside the school system of three parts, including: a) the implementation of the kindergarten of the preschool education; b) the school system in the primary school, secondary schools, junior art education schools, secondary vocational schools, technical worker training schools, technical schools, universities and colleges, etc.; c) outside the school system of all kinds of training institutions. In 2006, the Hungarian working population aged 25-64 with more than a high school education accounted for $75 \%$. Since the 1990s, the Hungarian education funds have been accounted for more than $5 \%$ of its gross national product (GNP), but because of economic decline, the total education funds is sustained, significant decline, education fund shortage problem in Hungary to the development of education.

In the field of public education, instead of the former force and the mandatory courses as mentioned above, a country's core curriculum (NCC) came into force in 1998. Revised every three years, NCC as a comprehensive framework provides the basic orientation, principles and objectives and concepts and methods to guide all public education institutions together. It also provides Suggestions for distribution percentage to express the total contact time. So, for each grade it awarded national content and methodology of the unity and coherence in the level of progress, but it is to achieve freedom to develop their own individual school Custom teaching plan and course place for their specific needs and potential. Further development of the basic concepts, in front of the two core curriculum, the recently revised NCR, in 2007-2008 academic years, while maintaining an interdisciplinary, interdisciplinary approach method, the definition of a strong focus on the whole teaching process is the acquisition of key skills in lifelong learning $[8,9]$.

\section{HUNGARY'S EDUCATION SYSTEM}

The Higher Education Act of 1993, the provision of higher education put forward the principle of democracy and 
the higher degree of autonomy of higher education opening to the outside, giving an unprecedented expansion of higher education. At present, the Hungarian education and training system, and the structure of education and organization is diverse, the content is, on the one hand, the product of many centuries of evolution reflects traditional European structure and values deeply rooted in national knowledge and cultural heritage; on the other hand, it reflects the Hungary after the beginning of 1990 in the world, especially under the background of Europe, the impact of the test of comprehensive social and economic and political. The double character of the system is characterized by obvious at all levels across the country, and between the disciples and devotees of the innovation and reform of the traditional socialist struggle. Over the centuries, this has been a permanent characteristics and teaching practice of education policy, and at the beginning of the 20th century and the influence of globalization coupling, unprecedented fast pace of technological progress, the industry is witnessing a growing pressure and profound transformation and the rapid concept to adapt to the society, economy, technology and the reality of the population. Although in the past two decades, many positive and spectacular qualitative and quantitative improvement, obvious weaknesses and adapt to difficult, criticize the performance of the system is now the consequences of these contradictions $[10,11,12]$.

In the Hungarian government bills, education policy always has priority. The government will education policy as promoting economic development, maintain social stability and the main methods of health. People believe that economic development depends on the advanced scientific knowledge, have stronger competitiveness of qualified workers, and also must constantly improve its quality. Only in this premise, Hungary will succeed in the future. Education is to cultivate such qualified workers for the society. Depends largely on the success of the development in the future the development direction of how to coordinate the various government departments, how to combine the basic principles of education policy throughout. The priority of education mainly reflects in:1) to improve population quality is the core of the Hungarian education policy; 2) in terms of accepting education, everyone equal opportunities; 3 ) education is the capital of knowledge economy, as well as one of the prerequisites of economic development.

According to the international comparative data of the average performance of Hungary's education and training system in terms of efficiency, quality is the delivery of knowledge and ability, at the request of the relationship between the knowledge-based society as well as the effective use of manpower and material resources, and hybrid. Although tangible achievements about several aspects of education and training, in recent years the basic international indicator measuring efficiency and fairness in education and training and most OECD countries stagnate or fall according to the performance of Hungary in these areas. Education and training of the most significant progress, it was the Hungarian society is dramatically improving population education achievement. Although basic demographic trends has been reflected in a stable, slow decline of school-age population scale, happened in the past 20 years the number of impressive growth and the proportion of young people admit that junior high school level general or vocational education. Today, more than $85 \%$ of the relevant age group to attend senior secondary level of education institutions. Results the proportion of patients with at least a junior high school education has more than doubled, especially at a young age brackets. The expansion of higher education has been more spectacular. In only ten years intervals, accept full-time university or college course of young people has quadrupled. There is no doubt that this development not only reflects the increase in demand for Labor and higher qualifications, and this is evidence of an obvious desire of society as a whole and personal gain better knowledge and skills. Even if the content and methods of modern education did not keep up with the expansion of senior secondary education and higher education, a significant progress has been made especially in the delivery of key ability, acquire specific skills $[13,14,15]$.

\section{A. Education Funding System}

Hungary funding mainly from the central government in accordance with the number of students of primary and secondary schools transfer, funds accounted for about 70$75 \%$ of the funds required for the school running, the remaining parts by the local government subsidies. Funds disbursed of institutions of higher learning practice on the basis of the cost of national tasks and disciplines of formula. At the same time, the ministry of education every seven years to a public university examination and evaluation, according to the result of examination and assessment to adjust the allocation base, on the basis of new balance amount shall be allocated.

\section{B. School Education System}

Before the transition, public school is the only school mode, until the 1990s, private education to gradually rise. At present, the Hungarian education system including national and the national university of the two classes, both are recognized by the Hungarian government, and accept the guidance of the government administrative department of education in our business. Institutions of higher learning and can be divided into two kinds of colleges and universities.

\section{Educational Management System}

The Hungarian government on implementing a management education work, i.e., the higher education by the ministry of education, primary and secondary school education by state governments, early childhood education by the town and the capital district government is responsible for.

\section{Schooling Systems}

Hungary's fixed number of year of the compulsory education for 12 years, the government to manage to the head. Its basic education system can be roughly divided into three levels: 6 years old children must be on primary school (divided into 6 or 8 years).After graduating from primary school can choose ordinary high school (4 years), vocational school (4 years), vocational school (in general) for 3 years, 
or junior college (usually 2 years).Students can pass the entrance examination of 18 to college (master degree, usually 5 to 6 years) or institute (specialized subject, generally 3 to 4 years).Hungary for public school students before the age of 22 free education system. Don't want to go to college students, but in the elementary school graduation (roughly equivalent to China's junior high school) choose a career after high school or college, in order to obtain the professional qualification certificate, is advantageous for the job. Hungary shall practice a system of free education before the age of 22, students who attend public schools, and don't have to pay the tuition before the age of 22; the fee shall be borne by the government in theory.

\section{E. University Autonomy}

University has a high degree of autonomy, not from the local government interference, for the principal, the only limitation is the must act strictly in accordance with the law. The headmaster in the school to accept supervision from the school board is responsible for the school board, the major issues of the school must submit the reception committee vote. The principal all professors nominated by the schools and the basic internal candidates for the university. Term for 3 years, can stay in power. Power must be the same as the first of the election process. The rector who selecting from the university, after reported to the Department of Education, while the Education Department reported to the President for approval. The election of the Ministry of Education to the university President has no right to interfere [16, 17, 18 ].

\section{THE FINANCIAL CRISIS IMPACT ON HUNGARIAN EDUCATION}

\section{A. Financial Crisis's Influence on the Hungarian economy, Society}

Statistics show that Hungary's economy grew $0.5 \%$ in 2008, the government fiscal deficit at $3.3 \%$ of GDP, the government and the private sector debt amount up to $107 \%$ of gross domestic product. Budapest stock market affected by the financial crisis, the main stock index fell $53.3 \%$ in 2008.In February 2009, Hungary's industrial production fell $25.4 \%$ year on year, and exports fell $30 \%$ year on year. Hungary was excessive open, even the banking system and according to the mode of financial operation. But due to the fragile financial system, dealing with international experience, financial institutions to small and weak, indebtedness, low levels of response to the crisis management, the imitation high deficit and debt in the United States economic model, external dependence is higher, and the external debt in foreign currency form is the third.

According to the analysis of Hungary days most affected by the crisis has not yet arrived, the economy will shrink by $6.7 \%$ this year, is expected to consumption in the second half of the year will reduce the 8-9\%.To cut costs in the workplace, the government to reduce all kinds of subsidies, freeze public sector wages, reduce the subsidies, such as the gas heating at the same time improve the sales tax, including tax from $20 \%$ to $25 \%$.Under financial pressure, a few days ago, the government decided to close its embassy in Chile, Luxembourg, 12 consulate abroad such as Venezuela, migration 3 overseas missions, financial input to reduce the price[19, 20, 21].

\section{B. Financial Difficulties Caused Educational Investment Reduced}

Hungary in the next few years will remain negative growth and ageing population, the effects of this on Hungary's public education is: 1) the need to accept education of population decline;2) have the ability to work is reduced, the population of the national tax and other revenue, so countries will cut spending on education. Hungary's past and future employment for a period of time is reduced, the unemployment rate increase. Employment structure changes at the same time, agriculture, industry, construction and other manual labor employment proportion dropped sharply, mental labor and service sector employment proportion increase at the same time, so the demand for higher education and vocational education. It is predicted that by 2016, 24-54year group have received secondary education in work ability of the population will increase the proportion of $10 \%, 57 \%$, have received higher education will be increased by $5 \%$, the proportion of people reached $22 \%$.Current Hungary has its advantages and the traditional concept of education development, but due to globalization and the development of new technology revolution, it also presents a lot of weak and needs to be improved, need to solve the problem of face, deal with the current financial crisis on the impact of education, deepen the education reform. Higher education basic decrease, make the higher education reform is difficult to maintain. Hungary in 2009 the education ministry of culture announced 70 institutions of higher education in Hungary, two points at the national university and the national universities, including 29 national university and college, the required basic education funds by the central finance allocates funds, so the education investment occupies a large proportion of the GDP. But in the spread of the global financial crisis situation, especially the Hungarian debt under the condition of high barrier, education investment is relatively difficult. Due to the overall economic slump, colleges and universities is facing unprecedented difficulties. In order to maintain the operation of schools, colleges and universities can only reduce the public service personnel to seek development [22, 23, 24, 25, 26].

\section{University Graduates Employment is Grim}

It is understood that due to the pressure of employment environment, society can provide employment dwindling, causing a lot of graduates to employment. Some students graduating in 2006, has not yet found a job, but they said there are a lot of employers, but not to hire staff. At the same time, college students graduation rates are falling, on the one hand is economic pressure big, 2 it is confused for the future, the third is unable to find a suitable job [26, 27, 28, 29]. 


\section{Serious Impact on the Confidence of the Educators and those Being Educated}

At present, the economic crisis, all have great influence on both educators and those being educated, especially on their confidence in the future. Educators do not have enough funds to support the scientific research work, educators face the uncertainty of future society and have confidence shaken, enthusiasm for learning and the pursuit of science as a few years ago[30, 31, 32].

\section{E. A vicious cycle}

The whole society of the dual role of education investment and family life pressure make education respectively from two aspects: social and individual happening a vicious cycle. Therefore, the education efficiency needs to be improved. School system has the characteristics of the present a good result, especially a high degree of autonomy. Occupational training school graduates, however, did not fully prepare to meet the labor market. Policies are conducive to the professional practice training of regional integration of vocational training center. For school effectiveness, the actual teaching of the ratio of the relative to the total legal working hours should be improved, but there is still room for further consolidation or contact municipal authorities. The government should improve the incentive to provide advanced research match labor market needs and to strengthen the students' conditions continue to receive free tuition, and to extend the way students from poor families to pay for the cost of living $[33,34,35]$.

\section{ACKNOWLEDGMENT}

This paper is sponsored by the fund of Humanities and Social Science of Ministry of Education, the project No. 11YJA190149 and the Humanities and Social Science Fund of South China University of Technology. Great thinks to these two funds.

\section{REFERENCE}

[1] Higher Education Institutions in, [Online]. Available: http://www. okm.gov.hu.

[2] The most popular Hungarian higher education institutions and programs in 2009, [Online]. Available: http://www. okm.gov.hu.

[3] Education in Hungary-Past, present, future-an overview, [Online]. Available: http://www. okm.gov.hu.

[4] Come and Study in Hungary, Higher education programes for foreign students in Hungary, [Online]. Available: http://www. okm.gov.hu.

[5] Education in Hungary-Past, present, future-an overview, [Online]. Available: http://www. okm.gov.hu.

[6] István Mészáros, The Thousand-Year Histor y of Schools in Hungary, Nemzeti Tankönyvkiadó, Budapest, 1999.

[7] National Summary Sheets on Education Systems in Europe and Ongoing Reforms, Hungar y, Eurydice, 2007.

[8] Education in Hungary 2006, Hungarian Institute for Educational Research and Development, Budapest, 2007, or [Online]. Available: http://http://www.ofi.hu.
[9] The New Hungary Development Plan (2007-2013), the Social Rene wal Operational Programme,Social Infrastr ucture Operational Programme, [Online]. Available: http://www.nfu.hu.

[10] Equity in Education, "Dimensions, Causes and Policy Responses", OECD country analytical report, Country sheets, 2007.

[11] Towards Bologna, The Hungarian Universitas Program - Higher Education Reform Project, [Online]. Available: http://okm.gov.hu.

[12] Strategy of the Government of the Republic of Hungary for Lifelong Learning, [Online]. Available: http://okm.gov.hu.

[13] Equity in Education. Dimensions, Causes and Policy Responses. OECD country analytical report, Country sheets, 2007.

[14] National system of innovation in Hungary, OECD Background Report, 2007.

[15] Characteristics of Hungarian Higher Education on an international perspects, NEFMI (Ministry of National Resources) statistics, [Online]. Available: http://www.nefmi.gov.hu/english.

[16] BARAKONYI, K., "Egyetemi kormányzás.Merre tart Európa? (University governance. Where is Europe headed?)", Kagazdasi Szemle (Economic Review), vol. LI, pp. 584-599, 2004.

[17] BAZSA, GY. "Nem a diák sok, a pénz kevés(There is not an abundance of students, but a lack offunds)", Népszabadság, p. 12, 2011.

[18] BERDE, é. - CZENKY, K. - GYOGYI, Z. - HíVES, T.- MORVAY, E. - SZEREPI, A., "Diplomával a munkaeriacon (Degree in hand on the labourmarket)", $2006 . \quad$ [Online]. Available: http://www.hier.iif.hu/hu/konf/Felsooktatasi_GYZ.pdf.

[19] FRIEDMAN, M., Kapitalizmus és szabadság(Capitalism and freedom), Akadémiai Kiadó. Budapest, 1996.

[20] KADOCSA, L. (2002): "Trendek a felsktatban I.(Trends in higher education I)", Magyar Felsktat, pp. 26-28, July 2002.

[21] KECZER, G. A magyar felsktatiry reformjai a lisszaboni stratégia tükrében(Reforms of Hungarian higher education managementin light of the Lisbon Strategy), In: Farkas B.(ed.): A lisszaboni folyamat és Magyarország (The Lisbon Process and Hungary), 2007.

[22] SZTE Gazdálkodástudományi Kar Klemyei (University of Szeged Communiqué of the Faculty of Economics and Business Administration). JATEPress, Szeged, 2007, pp. 173-186.

[23] LUKáCS, P., "Piaccá lett felsktat(Market-like higher education)", élet és Irodalom, vol.6. pp. 9-10, 2002.

[24] LUKáCS, P., "Teges felsktat -globális versenyben (Mass higher education - In global competition)", 2002. [Online]. Available: http://zskflnk.uw.hu/nk/Tomeges_felsookt.htm.

[25] MCMAHON, W. W., Education and Development: Measuring the Social Benefits, Oxford University Press, 2002.

[26] MOLNáR, T., Hogy lesznek így diplomásaink?(How will we have graduates this way?), 2011.

[27] [Online]. Available: http://index.hu/gazdasag/magyar/2011/05/19/felsooktatas/.

[28] SCHULTZ, T. W., Beruházás az emberite (Investing in human capital), Kgazdasi és Jogi Kiadó, Budapest, 1983.

[29] VARGA, J., Oktatás-gazdaságtan (Education-Economics), Kgazdasi Szemle Alapítvány(Economic Review Foundation), Budapest, 1998.

[30] VOSSENTEYN, H., Fiscal Stress: WorldwideTrends in Higher Education, 2004.

[31] "Finance. NASFAA". Journal of Student Financial Aid, vol.34. pp. 39-55.

[32] KSH (HCSO), Magyarország 2010(Hungary 2010), Budapest, 2011.

[33] NEFMI (Ministry of National Resources):Oktatás-Statisztikai kyv (Statistical Yearbook of Education) 2009/2010, Budapest, 2010.

[34] OECD, Education at a Glance, 2011, OECD indicators, OECD, 2011.

[35] OECD, Education at a Glance, 2009, OECD indicators, OECD, 2009. 